\title{
The upcoming recession due to Covid 19 and its impact on economic growth and the digital transformation in the Balkan region
}

\author{
Mila Mitreva, ${ }^{1}$ \\ Blagica Koleva, ${ }^{2}$
}

UDC 338.124.2]:616.98:578.834(497)

330.55:303.724]:616.98:578.834(497)

${ }^{1}$ University Goce Delcev Stip, Faculty of Economics, mila.mitreva@ugd.edu.mk
${ }^{2}$ University Goce Delcev Stip, Faculty of Economics, blagica.koleva@ugd.edu.mk

\begin{abstract}
The Covid-19 pandemic has affected the economy across the globe and generated uncertainties in the functioning of the industries, governments and the daily life of people. The impact that this crisis has on poverty alleviation, the global GDP and the rapid development of the digitalization process are some of the factors that have reshaped the world. Hence, the way in which the companies and different sectors have operated is now in the past. The new economic condition requires quick adaptability to the new trends and fast implementation of digital solutions. Therefore, new strategies and more advanced practices are a necessity not only for the proper functioning of the businesses, but for the governments and the countries as well. The rapid shift towards the digital channels caught many businesses off guard. All these fast changes and the late transformation slowed down the economic growth, mostly in the countries that did not reacted immediately. Considering that the Balkan region tried to provide digitally enhanced offerings and maintain the economic growth during the pandemic, many people were laid off, many business sectors were affected and many companies were closed. All these transformations affected the economic development and stagnated the growth. Therefore, the aim of this paper is to evaluate what are the main factors that have affected the economic growth in the Balkan region and the reason that contributed to digital transformation of these countries.
\end{abstract}

Key words: crisis, growth, economy, digitalization, economy

\section{Introduction}

Covid 19, which occurred at the end of 2019, was one of the most profound, serious health crisis that has happened in the history of the world. The preventive measures, which were introduced, created socio-economic turbulences, which deeply affected in a negative way many businesses in the long-run. Therefore, the global spread of the virus imposed many restrictions on the normal functioning of the economies, which consequently negatively affected the GDP growth. However, the negative effect was not equally distributed across the world. Some of the countries have quickly adapted to the new circumstances, especially those that managed to provide IT related serviced, while other countries were faced with closing off 
many businesses, increased number of unemployed people and disrupted supply chains. This outbreak reshaped the normality and significantly affected the most critical sectors such as the health, education, the production industry and the whole economy. The upcoming global recession is considered to push back millions of people into poverty and to increase the income inequalities among people. Considering everything that is mentioned above, the Balkan region was not an exception, where almost all of the Balkan countries experienced a decline in the domestic demand, decreased level of export, an increase in almost every product prices, disruptions in the supply chain, fiscal weakness and reduced levels of household income and consumption. Hence, some of the Balkan countries such as Montenegro, Albania and Kosovo, which rely much more on tourism compared to the other Balkan countries, experienced a decline in the tourism by 30 percent, which is around $24 \%$ higher compared to the decline that occurred during the previous financial crisis in 2007 . The GDP of these countries depends with more than $25 \%$ on the tourism, thus, consequently the losses that occurred during 2020 have deeply affected the economies of these countries. Furthermore, North Macedonia, $\mathrm{BiH}$ and Serbia, were mostly hit in the manufacturing industry, as well as the construction, tourism and the real estate, which created their fiscal balances to be negative after several years of surpluses [1]. Undoubtedly, the economic repercussions that have occurred due to the implementation of all of the interventions declined the domestic industry output and decreased the levels of international trade by $25-40 \%$. All of the behavioral, clinical and state interventions which were undertaken in order to prevent the spreading of the virus and maintain the situation stable, stabilized the transmission of the virus, but negatively affected the economy [2]. Considering the newly occurred situation, most of the countries shifted their way of functioning online, where children started studying online, most of the employees started working from home and many business models were reshaped towards the digital transformation in order to maintain their revenue flows. Hence, the digital acceleration imposed many challenges to the economies and societies worldwide. Thus, all things gathered together rise many question on how actually the crisis affected the Balkan region, how did the digitalization contributed to changing the way businesses were conducted and most importantly where does the future of the jobs, education, the health system and the governments lie. Therefore, the aim of this paper is to examine the upcoming recession due to Covid 19, its impact on economic growth and the digital future of the Balkan countries.

\section{Literature review}

The current, disrupted global economy, where millions of people have lost their jobs, with turbulent health systems and rising death tolls, leaves no way of telling exactly when will the economic damage recover and how long the virus will be potent. Although many fiscal and monetary expansion programs were implemented, the government debt of many countries is still rising. The borrowing costs are increasing across the governments globally and many stimulus packages were introduced, everything with one aim, to keep the economy sustainable. The slowdown of the economic operations, the lockdowns and transportation restrictions are some of the factors that affected the production level and the profitability of the companies. However, when it comes to the Balkan region, some of the support measures, which were imposed by the governments, included direct wage support, tax deferrals, direct cash payments or delayed mortgage payments. Nevertheless, these measures were aimed to mitigate the issues in the short run, but new measures and policies are needed in order to reach and remedy the real economy in long run [3]. 
Moreover, boosting the economic growth is priority for many countries worldwide. Therefore, minimizing the level of poverty, decreasing the number of unemployed people and implementing adequate government policy measures are some of the factors that stimulate the governments to stabilize the economy of their countries. Hence, when it comes to economic growth, FDI is key factor that can stimulate the growth, especially for developing countries, because it increases the level of employed people, which consequently boosts the living standard and the spending power of the people. According to Borensztein et al (1998), $1 \%$ increase in FDI contributes to $0.8 \%$ increase in GDP. Furthermore, Desai et al. (2005) found that $10 \%$ increase in FDI, increases the domestic investment by $2.2 \%$, while Kim and Seo (2003) in their paper also found that the effects of FDI on the economic expansion are positive. Nevertheless, inflation also is an important factor when the aim is to achieve high economic growth. When the inflation level increases, the general price level of various types of goods also increases. Taking into consideration that during the corona period, the prices for goods and services have increased drastically, it provides a good basis to analyze if this variable had an actual impact on the economic growth of the Balkan countries [4]. Furthermore, the literature claims that when a crisis hits a country, the economic growth is considered to be mostly affected. Hence, the types of policies which will be applied from the governments will have profound impact on the stability of the economy. Moreover, remittances are also considered to have an impact on the economic growth on the Balkan countries. In 2018, remittances in Albania were 170 million euros, while in Kosovo they were 70 million. The remittances in these countries were not used for investment projects, but, for decreasing the poverty rates. Furthermore, around $25 \%$ of the households in Kosovo rely on remittances, which usually come from Switzerland, Germany and USA. From the Balkan countries, Croatia has the highest level of net remittances per person, which is around 500 euros. Although these remittances help some households to get out of poverty, recent studies have found that they negatively affect exports [8]. According to Kumar et al. (2018), around $50 \%$ of the remittances in $\mathrm{N}$. Macedonia is spent on consumption, while the rest is spent on education, business, health and repayment of debts. Moreover, export also plays an important role in stimulating the economic growth. The export level in N. Macedonia is around $12 \%$ of its GDP, while in Serbia it is 10\%, in Bosnia and Herzegovina is around 6\% and in Kosovo is the lowest, around $2 \%$ [9]. Hence, broadly speaking, export growth and economic growth are positively associated. According to Lee and Huang (2002), if two-regime MTAR model is applied there is a strong positive relationship between exports and GDP growth. Therefore, considering the provided literature between some of the variables of interest, such as remittances, export, inflation, FDI, the aim of this paper is to analyze different factors which are considered to had an impact on the economic growth during the year 2020 for the Balkan countries.

\section{Data analysis and interpretation of results}

For determining which variables had an impact on the economic growth, the analysis for the established model was conducted in E-views. As dependent variable was taken the GDP, while as independent were remittances, export, FDI and inflation. For the purpose of the analysis, one model was build with yearly observations for 2019 and 2020 . The aim was to compare if any of the independent variables had an actual impact on the economic growth of the Balkan countries during the pandemic in 2020.

Furthermore, the data for this study has been gathered from secondary sources, mainly from the World Bank website. 
Model: GDP $_{\text {it }}=$ constant + REM it $+\mathrm{EXP}_{\text {it }}+\mathrm{FDI}_{\text {it }}+\mathrm{INFL}_{\text {it }}+\varepsilon_{\text {it }}$

The initial step of the analysis included testing for stationarity, unit root test. If the probability of any of the unit root tests is less than $1 \%, 5 \%$ or $10 \%$, which is the level of significance, it means that the $\mathrm{H}_{0}$ is rejected. From the obtained results, the probability for the tested variables is less than the level of significance, hence, it can be concluded that the variables do not have unit root. In other word, all of them are stationary.

Table 1: Unit root test

\begin{tabular}{|c|c|c|c|c|}
\hline \multicolumn{5}{|c|}{ Group unit root test: Summary } \\
\hline \multicolumn{5}{|c|}{ Series: GDP, REMITTANCES, EXPORT, FDI, INFLATION } \\
\hline & & & Cross- & \\
\hline Method & Statistic & Prob. ${ }^{\star \star}$ & sections & Obs \\
\hline \multicolumn{5}{|c|}{ Null: Unit root (assumes common unit root process) } \\
\hline Levin, Lin \& Chu t* & -2.43413 & 0.0075 & 5 & 82 \\
\hline \multicolumn{5}{|c|}{ Null: Unit root (assumes individual unit root process) } \\
\hline $\begin{array}{l}\text { Im, Pesaran and Shin W- } \\
\text { stat }\end{array}$ & -3.15481 & 0.0008 & 5 & 82 \\
\hline ADF - Fisher Chi-square & 27.6805 & 0.0020 & 5 & 82 \\
\hline PP - Fisher Chi-square & 62.9769 & 0.0000 & 5 & 85 \\
\hline
\end{tabular}

From the table below it can be seen that the data for remittances, export and inflation is skewed to the right (due to the positive sign), while the data for GDP and FDI is skewed to the left (due to the negative sign). Moreover, it can be seen that the distribution is not normal, because for all of the variables in the model, the kurtosis is more than 2. However, the JarqueBera results show that the probability is higher than $5 \%$ level of significance, thus $\mathrm{H}_{\mathrm{o}}$ is accepted. ( $\mathrm{H}_{0}=$ normal distribution). Moreover, considering that the standard deviation is more than 1 for most of the variables, it can be said that there exists a relatively high variation in every variable.

Table 2: Descriptive statistics

\begin{tabular}{|l|c|c|c|c|c|}
\hline & GDP & REMITTANCES & EXPORT & FDI & INFLATION \\
\hline Mean & -1.226709 & 7.762482 & 47.00118 & $-1.04 \mathrm{E}+09$ & 1.002194 \\
\hline Median & 0.596989 & 7.768784 & 45.84382 & $-6.87 \mathrm{E}+08$ & 0.985947 \\
\hline Maximum & 4.941932 & 18.86758 & 83.74322 & 55438494 & 3.103729 \\
\hline Minimum & -15.15898 & 1.054432 & 21.99593 & $-3.97 \mathrm{E}+09$ & -1.051296 \\
\hline Std. Dev. & 5.599211 & 5.067410 & 18.11205 & $1.10 \mathrm{E}+09$ & 1.056575 \\
\hline Skewness & -0.833870 & 0.417010 & 0.427028 & -0.594474 & 0.097525 \\
\hline Kurtosis & 2.984992 & 2.556088 & 2.372629 & 4.602817 & 2.582993 \\
\hline & & & & & \\
\hline Jarque-Bera & 0.086187 & 0.669486 & 0.842255 & 0.553813 & 0.158954 \\
\hline Probability & 0.352363 & 0.715522 & 0.656307 & 0.108422 & 0.923599 \\
\hline
\end{tabular}




\begin{tabular}{|l|c|c|c|c|c|}
\hline & & & & & \\
\hline Sum & -22.08076 & 139.7247 & 846.0213 & $-1.87 \mathrm{E}+10$ & 18.03949 \\
\hline Sum Sq. Dev. & 532.9698 & 436.5370 & 5576.788 & $2.04 \mathrm{E}+19$ & 18.97796 \\
\hline & & & & & \\
\hline Observations & 18 & 18 & 18 & 18 & 18 \\
\hline
\end{tabular}

In the table below are presented the results for the correlation between the variables. The correlation coefficient for each variable shows the degree to which the movement of the variables is associated. Having into consideration that the values cannot be more than 1 or less than -1 , it can been said that between the variables exists both positive and negative correlation. There is no value of 0 , which usually indicates no relationship between the variables.

Table 3: Test for correlation

\begin{tabular}{|c|c|c|r|r|r|}
\hline & GDP & REMITTANCES & EXPORT & \multicolumn{1}{c|}{ FDI } & INFLATION \\
\hline GDP & $\mathbf{1 . 0 0 0 0 0 0}$ & -0.132072 & 0.298309 & -0.180365 & 0.583663 \\
\hline $\begin{array}{c}\text { REMITTANCE } \\
\text { S }\end{array}$ & -0.132072 & $\mathbf{1 . 0 0 0 0 0 0}$ & -0.878101 & 0.154246 & -0.162745 \\
\hline EXPORT & 0.298309 & -0.878101 & $\mathbf{1 . 0 0 0 0 0 0}$ & -0.071752 & 0.201452 \\
\hline FDI & -0.180365 & 0.154246 & -0.071752 & $\mathbf{1 . 0 0 0 0 0 0}$ & -0.403869 \\
\hline INFLATION & 0.583663 & -0.162745 & 0.201452 & -0.403869 & $\mathbf{1 . 0 0 0 0 0 0}$ \\
\hline
\end{tabular}

Table 4: Regression analysis

\begin{tabular}{|c|c|c|c|c|}
\hline Variable & $\begin{array}{r}\text { Coefficien } \\
\mathrm{t}\end{array}$ & Std. Error & t-Statistic & Prob. \\
\hline REMITTANCES & \begin{tabular}{|l|}
0.589055 \\
\end{tabular} & 0.491774 & 1.197817 & 0.2524 \\
\hline EXPORT & 0.203434 & 0.137936 & 1.474844 & 0.1641 \\
\hline FDI & $1.13 \mathrm{E}-11$ & 1.19E-09 & 0.009480 & 0.9926 \\
\hline INFLATION & 2.855036 & 1.233080 & 2.315370 & 0.0376 \\
\hline $\mathrm{C}$ & -18.21044 & 10.21442 & -1.782818 & 0.0980 \\
\hline R-squared & 0.439945 & & & \\
\hline F-statistic & 2.553004 & & & \\
\hline Prob(F-statistic) & 0.089134 & & & \\
\hline
\end{tabular}

In Table 4 are presented the regression results. Therefore, the regression coefficients for all of the Balkan countries show that the significant variables for 2019 and 2020 is only inflation. Hence, inflation is positive and significant at $5 \%$ and $10 \%$ level of significance, while the rest of the variables show no relationship with the dependent variable in both years. Furthermore, from the $R^{2}$ results, it can be seen that $44 \%$ of the dependent variable is explained by the variability of the independent variables, while $56 \%$ is explained by other factors [5]. Although in this analysis the results show no significant association with the dependent variable, the reason may be due to the fact that the sample size is very small. However, similar analysis 
was conducted in the paper of Nawaz et al. (2014) where they investigate the relationship between the GDP as dependent variable and two of the independent variables that they have used are used as well in the model in this paper. Hence, in their paper they have found significant association.

Undoubtedly, the Covid crisis created devastating consequences for the Balkan countries, which experienced a drastic decline in their GDP growth which can be seen in the graph below. The results showed that inflation had an impact on the GDP growth both in 2019, when the crisis occurred and in 2020. However, from the graph it can be seen that the inflation level did not increase equally in 2020 for all of the Balkan countries. More specifically, an increase in 2020 was detected in Albania and North Macedonia, while in the other countries the level of inflation had decreased in 2020 compared to 2019.
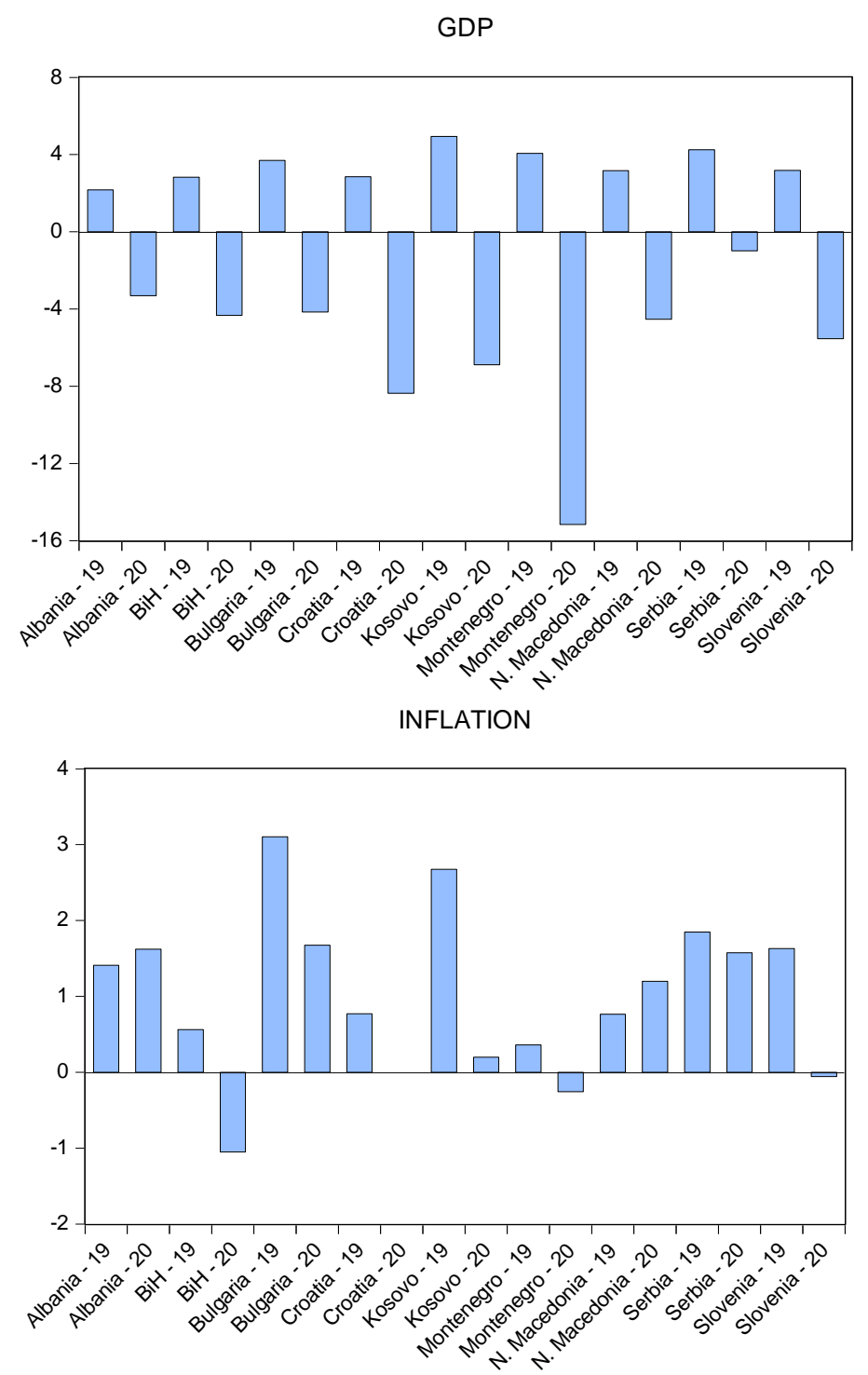

Moreover, although in the regression model, FDI did not show significant association with the GDP growth, from the graph below it can be seen that the level of FDI has drastically decreased in 2020, especially in Bulgaria, Croatia, Serbia and a slight decrease in N. Macedonia. It is worth mentioning that FDI is very important for the developing countries, because their companies have a necessity for multinational funding in order to expand their domestic and international sales, to increase the number of job offerings and to develop their 
business into more stabilized one in a long run. This is due to the fact that the market capacity of these countries is insufficient and they have lower level of their income per capita [6]. Although most of the existing theory, some of it is mentioned in the literature review, claims that FDI has an effect on the GDP, the results in this study may support the findings of Kogut and Singh (1998), who found that FDI has no effect on GDP growth [7].

FDI

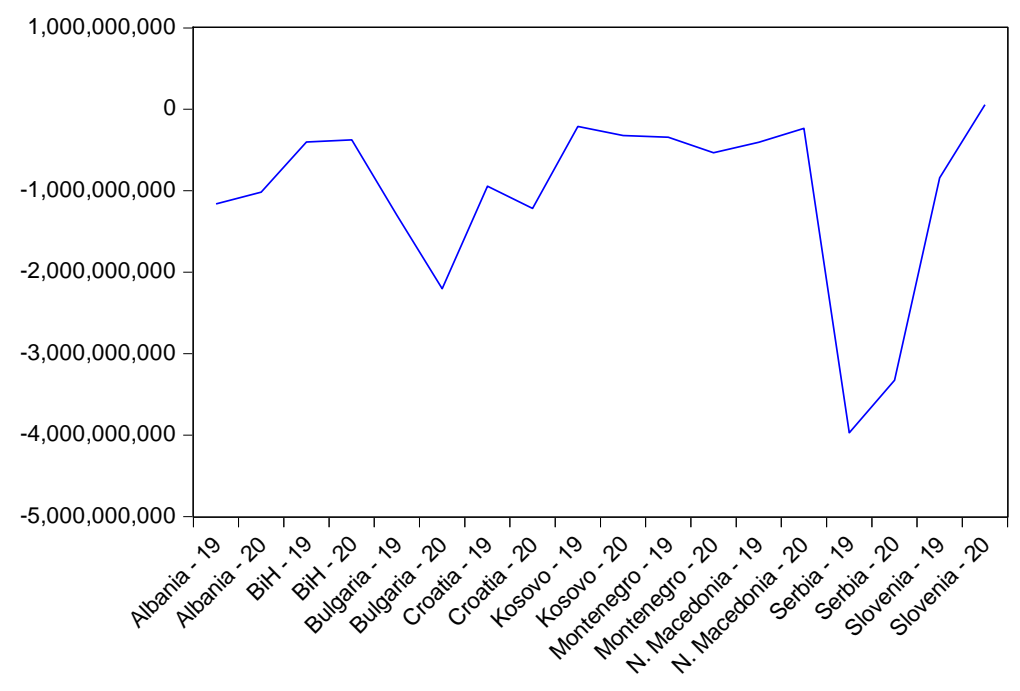

Theory claims that FDI and remittances play vital role for economic growth. Rao and Hassan (2012) in their paper through the Solow model found that remittances have positive impact on economic growth, contrary Karagoz (2009) through the Johansen cointegration test found that remittances and growth do not have a sustainable relationship. Cooray (2012), through the OLS, GMM and FE and RE model found that remittances are positively associated with the levels of growth. However, the results that were obtained in this paper may be supported by the study of Alkhathlan (2013) who found that in short term remittances do not have impact on economic growth. This may be explained again with the limitation of the time span and the number of observations, which were taken in this study. This non-significant relationship may be also supported by the paper of Mundaca (2009), in which it was estimated that remittances do have an impact on the economic growth, but only in developed markets. This finding is also claimed in the paper of Eggoh et al. (2019), where they found that remittances trigger the economic growth, but only if the country has well developed financial system [8]. Therefore, this is not the case for the Balkan countries, considering that they are classified as developing markets. 


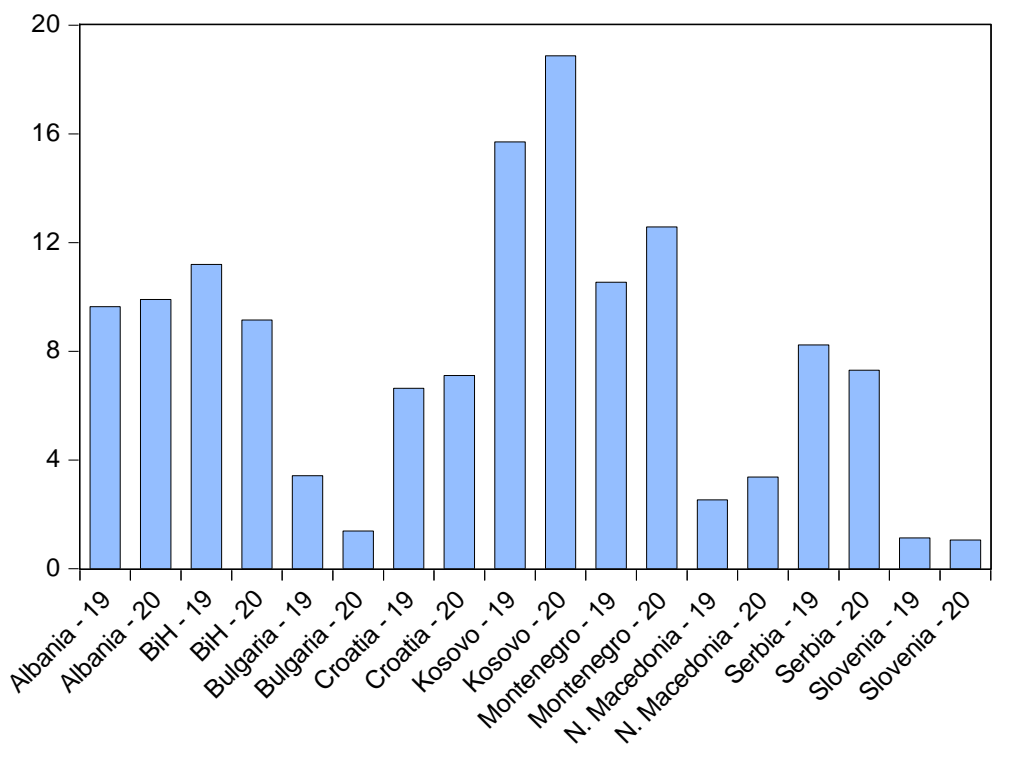

The obtained results in this paper showed no significant association between the GDP growth and the export levels. However, from the graph below it may be seen that the level of exports have decreased in 2020 compared to 2019. For comparison, in the paper of Lee and Huang (2002), it was found that economic growth leads to an increase in the exports, but, export does not have an impact on economic growth. Hence, the possible explanation may be the fact that GDP has actually decreased in 2020, in the same way the exports, for all of the tested Balkan countries. Therefore, when examining if export had affected this countries during the pandemic, no significant results were detected.

EXPORT

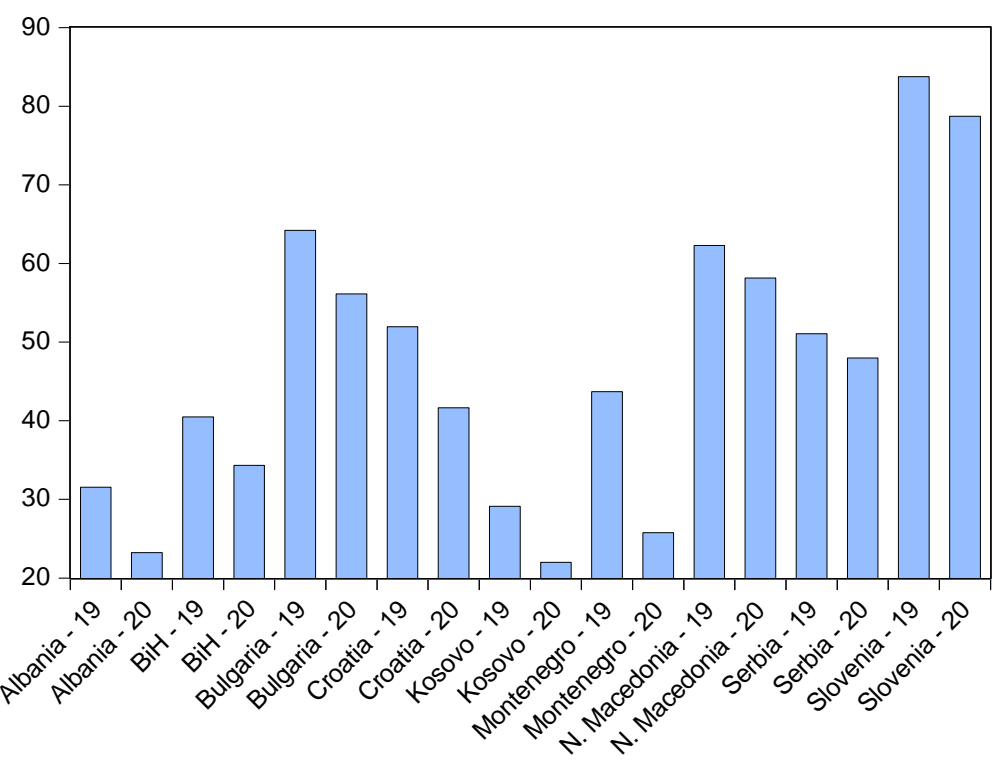


Table 5: Regression analysis with dummy variable

\begin{tabular}{|c|r|r|r|r|}
\hline REMITTANCES & 0.013603 & 0.325728 & 0.041762 & 0.9674 \\
\hline EXPORT & 0.030029 & 0.092338 & 0.325212 & 0.7506 \\
\hline FDI & $-4.00 \mathrm{E}-10$ & $7.36 \mathrm{E}-10$ & -0.543820 & 0.5965 \\
\hline INFLATION & 1.064190 & 0.846897 & 1.256575 & 0.2328 \\
\hline CRISIS & -8.157803 & 1.722746 & -4.735348 & 0.0005 \\
\hline C & -0.148077 & 7.345144 & -0.020160 & 0.9842 \\
\hline
\end{tabular}

In regression analysis, dummy variable is usually added to detect if there is an absence or presence of some particular effect. Therefore, in this paper the dummy variable was added to determine if the corona crisis had an actual impact on the GDP growth. Hence, the results show significant and positive association with the dependent variable at $1 \%, 5 \%$ and $10 \%$ level of significance. Thus, it can be concluded that the crisis had an actual impact on the decreased levels of GDP growth in the Balkan countries.

Last but not least, it is worth mentioning that the digitalization process have reshaped the way Balkan countries used to operate. Although the Balkan countries are known for their informal economies, low income levels and small population, during the pandemic they managed to develop e-commerce platforms that in some way helped in stabilizing the economy. According to the 2020 Balkan Business Barometer, 83\% of the population are internet users. Moreover, $62 \%$ of the respondents claim that they have increased their online shopping, while $85 \%$ of them will continue to shop online. Undoubtedly, the Covid crisis opened up an opportunity for e-commerce in the Balkan region, which was something uncommon for these countries.

\section{Conclusion}

There is an emerging literature that focuses on analyzing the factors that have an impact on the economic growth. Having a stable GDP growth is crucial for the economic prosperity of the country. Nevertheless, taken generally, the Balkan countries are small economies that are vulnerable to external shocks. The Covid pandemic did have an impact not only on these countries, but on the whole world. On one hand, the economies worldwide have faced turbulences, but on the other had, the prosperity for e-commerce and online working has increased. Therefore, the aim of this paper is to analyze if the corona crisis had an impact on the economic growth of the Balkan countries. The model consisted of GDP growth as dependent variable, while remittances, export, inflation and FDI as independent. The regression results showed that inflation was the only variable that affected the GDP growth in 2019 and 2020, while no significant association was detected with the other variables. The possible explanation may be the fact that the time span which is analyzed and the number of observations are limited. However, when added a dummy variable, it was proven that the corona crisis did have an impact on the GDP growth of the Balkan countries. 


\section{References}

1. World Bank Group [Internet]. Western Balkans regular Economic Report. The Economic and Social impact of Covid-19, 2020. Available from: https://documents1.worldbank.org/curated/en/606131588087679463/pdf/TheEconomic-and-Social-Impact-of-COVID-19-Western-Balkans-Outlook.pdf

2. Verschuur J, Koks E, Hall J. Global economic impact of Covid 19 lockdown measures stand out in high-frequency shipping data. 2021 April; 1-16.

3. Kumar M. The world after Covid-19 and its impact on global economy. Leibniz Information Centre for Economics; 2020, 1-12.

4. Nawaz M, Rafiq M, Mehmood A, Adbullah M, Hussain M. Which factors influence the economic growth of the country? Evidence with reference to Pakistan. Journal of Economics and Sustainable Development, 2014, 5 (19), 111-122.

5. Brooks C. Introductory econometrics for finance $2^{\text {nd }}$ edition. New York: Cambridge University Press.

6. Sucubasi B, Trenovski B, Imeri B, Merdzan G. The effects of FDI on domestic investments in Western Balkans. Globalization and its Socio-Economic Consequences. 2020, 92, 1-14.

7. Kogut $B$, Singh $H$. The effects of national culture on the choice of entry mode. Journal of International Business Studies. 1988, 19(3), 411-432.

8. Jushi E, Hysa E, Cela A, Panait M, Voica M. Financing growth through remittances and foreign direct investment: evidence from Balkan countries. Journal of Risk and Financial Management. 2021, 14 (117), 1-17.

9. Jusufi G, Ballaqa B. Trade Bariers and exports between Western Balkan countries. Sciendo, 2019. 